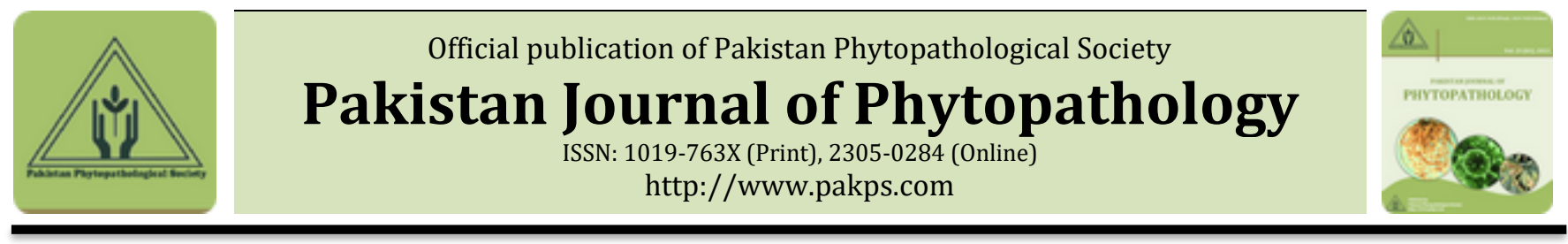

\title{
OPTIMIZATION OF KING OYSTER MUSHROOM (PLEUROTUS ERYNGII) PRODUCTION AGAINST COTTON WASTE AND FENUGREEK STRAW
}

\author{
aWaseem Iqbal, aMuhammad M. Jahangir*, aChaudhary M. Ayyub, bNasir A. Khan, cGhufrana Samin, \\ aMuhammad A. Khatana \\ a Institute of Horticultural Sciences, University of Agriculture, Faisalabad, Pakistan. \\ ${ }^{b}$ Department of Plant Pathology, University of Agriculture, Faisalabad, Pakistan. \\ 'Department of Chemistry, University of Engineering and Technology Lahore, Faisalabad Campus, Pakistan.
}

\begin{abstract}
A B S T R A C T
King oyster (Pleurotus eryngii) mushroom is a palatable mushroom with high commercial potential due to relative ease of its growing technology, less cost of production and better yield potential, making it popular throughout the world. Therefore, an experiment was set up to assess the efficacy of different agro-wastes [cotton waste (CW) and fenugreek straw (FS)] on the morphology, yield and nutritional components of two strains (Pleurotus eryngii P9 strain and Pleurotus eryngii P10 strain) of Pleurotus eryngii. Studied indicators regarding time for pinhead formation, fruiting body development, biological efficiency and yield of both strains were significantly affected by different formulations of substrates. Substrates with $100 \%$ CW exhibited maximum number of pinheads, yield and biological efficiency for both strains of king oyster as compared to other substrates alone or in mixture. This experiment indicates the possibility of Pleurotus eryngii cultivation on cotton waste and fenugreek straw in controlled conditions for enhanced growth and yield.
\end{abstract}

Keywords: Biological efficiency, Cotton waste, Fenugreek straw, Pleurotus eryngii

\section{INTRODUCTION}

Pleurotus eryngii mushroom is becoming globally popular because of its outstanding uniformity of cap and stem, gastronomic abilities and extensive shelf life. King oyster is a well-known mushroom suitable for consumption of human and famous for its unique aroma and taste. It belongs to Mediterranean area of Europe and now becoming popular all over the world including China, Japan, and Middle East and in Indo-Pak. King oyster mushroom is one of the greatest mushroom due to its better shelf life and gastronomic properties (Yildiz et al., 2002). It produces less spores than other oyster species that's why this strain has less vulnerability to getting allergy. Due to the plentiful contents of carbohydrates,

Submitted: March 22, 2018

Revised: July 06, 2018

Accepted for Publication: December 17, 2018

* Corresponding Author:

Email: muzammil_jahangir@hotmail.com

(C) 2017 Pak. J. Phytopathol. All rights reserved. minerals (i.e. phosphorus, sodium, potassium and calcium), protein, fibres, vitamins (i.e. D, B6, riboflavin, B5, niacin and B1 etc.) etc., King oyster mushroom acts as a promising health beneficial mushroom (Ahmad et al., 2009).

It also comprises diverse types of volatile compounds (Mau et al., 1998). Laccases are also present in King oyster mushroom which are being used in food and beverage industry for unwanted phenolics eradication for control of browning in food items. It has commercial importance due to its use on industrial scale. Compounds i.e. polyphenols, amino acids, polysaccharides and flavonoids etc. having antioxidant properties are also present in king oyster mushroom which play role in health maintenance. King oyster mushroom have nutritional value containing carbohydrates (9.6\%), dietary fibre (4.64\%), polysaccharides $(0.41 \%)$, chitin $(0.50 \%)$ and protein contents (1.88\% to $2.65 \%)$ ). It also contains different types of amino acids such as arginine, aspartic and glutamic acid (Manzi et al., 2004). 
Different commercially grown strains of Pleurotus eryngii are available and are being cultivated on large scale worldwide. Different strains respond differently regarding yield, quality of mushroom, mycelium growth against different environmental conditions, substrates, supplements and their quantity, (Visscher, 1989). Cultivation of king oyster is easy on straw of rice, wheat, sawdust and cotton waste (Jiskani, 1999). Optimum temperature range for fruit body development of King Oyster and other strains of oyster mushroom ranges between $12-17{ }^{\circ} \mathrm{C}$. Extensively yearround cultivation of $P$. eryngii is difficult as compared to other oyster mushroom strains i.e. P. florida, P. sajorcaju and $P$. ostreatus because it requires controlled conditions (Moonmoon et al., 2010).

Different wastes of food and agricultural industry i.e. cereal straws, saw dust, vegetable biomass, waste of paper and food industry and wood shavings etc. which contain plenty of lignin and cellulose can be considered as promising substrates for fruit body development and mycelium growth. Numerous enzymes are present in Pleurotus spp. which can decompose complex compounds present in industrial and agro-based wastes. Several substrates like sawdust, wheat and rice straw, cotton seed hull, sugarcane bagasse, corn stover and their combinations in different ratios with wheat bran, soybean and peanut meal can be used as growing media for King oyster mushroom on commercial scale. The optimum conditions for growth and development of fruiting body are temperature $\left(15-21^{\circ} \mathrm{C}\right)$, humidity (85-95\%) and light (500-1000 lux). Commonly 50-55 days are obligatory for accomplishment of mycelial growth and 3-4 flushes are obtained.

King oyster mushroom cultivation should be carried under control temperature and humidity level. Small amount of agricultural wastes are utilized effectively whereas large amount of wastes are disposed of or fired which cause serious damage to environment and human health.

At present, very scarce or no literature is available on evaluation of cotton waste and Fenugreek substrates for production of Pleurotus eryngii. Keeping in view this gap, a study was conducted to assess the outcome of Cotton waste and Fenugreek straw (alone and in combination) on different strains $\left(\mathrm{P}_{9}\right.$ and $\left.\mathrm{P}_{10}\right)$ of Pleurotus eryngii under controlled conditions. In this experiment cotton and fenugreek based substrates were used to optimize the growth and development of king oyster mushroom.

\section{MATERIALS AND METHODS}

Present research experiment was conducted in Medicinal and Mushroom lab at Institute of Horticultural Sciences, University of Agriculture, Faisalabad, in 20142016, to check growth, yield and biological efficiency of two strains $\left(\mathrm{P}_{9}\right.$ and $\left.\mathrm{P}_{10}\right)$ of king oyster mushroom (Pleurotus eryngii) on different growing media.

Preparation and bag filling of substrate: Different substrates such as cotton waste $\left(\mathrm{T}_{0}=100 \%\right)$ and fenugreek straw $\left(\mathrm{T}_{1}=100 \%\right)$ were used along with different combinations $\left(\mathrm{T}_{2}=25 \% \mathrm{CW}+75 \% \mathrm{FS}\right)$, $\left(\mathrm{T}_{3}=\right.$ $50 \% \mathrm{CW}+50 \% \mathrm{FS})$ and $\left(\mathrm{T}_{4}=75 \% \mathrm{CW}+25 \% \mathrm{FS}\right)$ respectively. Both substrates were dipped in water followed by heaping and covering with polythene sheet followed by fermentation for 4 days. Whereas excess moisture was removed by spreading substrates on floor till attaining the ultimate moisture content of $70 \%$. Substrates were filled in polythene bags of size $(20 \times 30)$ $\mathrm{cm}$ by following combinations given above and bags opening were loosely tied with rubber band. For the maintenance of $\mathrm{pH}, 2 \%$ lime was added.

For sterilization and pasteurization, local method was adopted by placing bags for two hours in ordinary drum having water in bottom with heating, followed by subsequent cooling for one day. Finally, spawn of strains $\left(\mathrm{P}_{9}\right.$ and $\mathrm{P}_{10}$ ) of Pleurotus eryngii were added at the rate of $1 \%$ per bag.

Growing Conditions: Optimum growing conditions were maintained by keeping temperature and $\mathrm{RH}$ at $20-24^{\circ} \mathrm{C}$ and $70-80 \%$ respectively for spawn running. While temperature after completion of mycelial growth was lowered and kept between $16-22^{\circ} \mathrm{C}$ with increase relative humidity (80-90\%) for successful onset of fruiting body.

Parameters: Different parameters like number of days for initiation of spawn running, number of days for $25 \%$, $50 \%, 75 \%$ and $100 \%$ mycelium growth, number of days for initiation of pinhead formation, number of pinhead formation/bag, total flushes/ bag, number of days to complete $1^{\text {st }}, 2^{\text {nd }}$ and $3^{\text {rd }}$ flush, yield/bag (g), biological efficiency (\%), pH of mushroom, total soluble solids, moisture percentage (\%) and fresh weight of mushroom were studied following standard procedure (Ahmed et al., 2009).

Statistical procedure: Two factor factorials under completely randomized design was applied in this experiment. Data collected was analysed by using ANOVA techniques. Means values were compared by using LSD test at $1 \%$ probability level. 


\section{RESULTS}

Results regarding various parameters such as biological efficiency, yield, moisture \% and subsequent number of days for $1^{\text {st }}, 2^{\text {nd }}$ and $3^{\text {rd }}$ flush were significantly affected by types of substrates used along with their varying concentrations respectively. $\mathrm{T}_{\mathrm{o}}$ yielded highest weight (280-290 g) followed by $\mathrm{T}_{4}$ which recorded (272-283 $\mathrm{g}$ ) in both strains ( $\mathrm{P}_{9}$ and $\mathrm{P}_{10}$ ) respectively (Figure 1). Whereas similar pattern was followed in case of biological efficiency, where $\mathrm{T}_{0}$ attains maximum biological efficiency (72 \%) of both strains ( $\mathrm{P}_{9}$ and $\left.\mathrm{P}_{10}\right)$ followed by combination $\mathrm{T}_{4}$ that recorded (67.5 and 69\%) in ( $\mathrm{P}_{9}$ and
$\mathrm{P}_{10}$ ) respectively. Meanwhile, $\mathrm{T}_{0}$ also influences time taken for $100 \%$ mycelial growth by recording least number of days (62.5), followed by $\mathrm{T}_{4}$ with (65.6 days), $\mathrm{T}_{3}$ having (67.4), $\mathrm{T}_{2}$ recording (67.9) and maximum number of days by $\mathrm{T}_{1}$ that recorded 70.4 days (Table 1 ). Number of days taken to $1^{\text {st }}, 2^{\text {nd }}$ and $3^{\text {rd }}$ flushes were also highly affected by substrate composition and type with $\mathrm{T}_{0}$ being the earliest one (83.9, 98.8 and 114.1 days), followed by $\mathrm{T}_{4}$ (88.1, 101.9 and 117.7 days) and maximum by $\mathrm{T}_{1}(89.5$, 113.9 and 119.9 days) respectively (Table 1). Similar result pattern was found in case of time taken for Pin Head initiation (Table 2).

Table. 1. Morphological attributes responses of P. eryngii against cotton ginning waste and fenugreek straw

\begin{tabular}{ccccccccc}
\hline \multirow{2}{*}{ Treatments } & \multicolumn{2}{c}{$\begin{array}{c}\text { Time taken for 100\% } \\
\text { mycelial growth }\end{array}$} & \multicolumn{2}{c}{$\begin{array}{c}\text { Time taken for } 1^{\text {st }} \\
\text { flush }\end{array}$} & \multicolumn{2}{c}{$\begin{array}{c}\text { Time taken for } 2^{\text {nd }} \text { flush } \\
\text { (Days) }\end{array}$} & $\begin{array}{c}\text { Time taken for } 3^{\text {rd }} \text { flush } \\
\text { (Days) }\end{array}$ \\
\cline { 2 - 9 } & P9 & P10 & P9 & P10 & P9 & P10 & P9 & P10 \\
\hline $\mathrm{T}_{0}$ & $61.4 \pm 0.5$ & $63.6 \pm 0.7$ & $81.9 \pm 0.8$ & $85.9 \pm 1.7$ & $96.7 \pm 0.8$ & $100.9 \pm 0.8$ & $111.3 \pm 0.9$ & $117.0 \pm 1.0$ \\
$\mathrm{~T}_{1}$ & $72.6 \pm 0.5$ & $68.1 \pm 1.0$ & $91.7 \pm 1.8$ & $87.3 \pm 2.1$ & $104.6 \pm 1.9$ & $103.3 \pm 2.0$ & $119.1 \pm 1.9$ & $118.7 \pm 1.9$ \\
$\mathrm{~T}_{2}$ & $67.0 \pm 0.6$ & $68.7 \pm 0.5$ & $90.3 \pm 2.1$ & $90.0 \pm 1.3$ & $103.6 \pm 1.8$ & $104.3 \pm 1.3$ & $118.6 \pm 1.5$ & $119.9 \pm 1.2$ \\
$\mathrm{~T}_{3}$ & $68.4 \pm 0.5$ & $66.3 \pm 1.0$ & $85.1 \pm 0.8$ & $90.3 \pm 1.3$ & $99.9 \pm 0.6$ & $104.7 \pm 1.4$ & $116.4 \pm 0.9$ & $119.4 \pm 1.2$ \\
$\mathrm{~T}_{4}$ & $68.3 \pm 0.7$ & $62.9 \pm 0.8$ & $88.3 \pm 1.3$ & $87.9 \pm 0.7$ & $102.0 \pm 1.0$ & $101.9 \pm 0.5$ & $117.4 \pm 0.8$ & $118.0 \pm 0.8$ \\
\hline
\end{tabular}

Table.2. Morphological attributes responses of $P$. eryngii against cotton ginning waste and fenugreek straw

\begin{tabular}{ccccccc}
\hline \multirow{2}{*}{ Treatments } & \multicolumn{2}{c}{ Time taken for pinhead formation (days) } & \multicolumn{2}{c}{ No. of Pinheads } & \multicolumn{2}{c}{ Fresh weight of mushroom (g) } \\
\cline { 2 - 6 } & $\mathrm{P}_{9}$ & $\mathrm{P}_{10}$ & $\mathrm{P}_{9}$ & $\mathrm{P}_{10}$ & $\mathrm{P}_{9}$ & $\mathrm{P}_{10}$ \\
\hline $\mathrm{T}_{0}$ & $74.9 \pm 1.2$ & $79.6 \pm 1.0$ & $32.6 \pm 0.9$ & $29.6 \pm 1.3$ & $269.6 \pm 2.9$ & $268.0 \pm 3.0$ \\
$\mathrm{~T}_{1}$ & $81.9 \pm 2.4$ & $78.7 \pm 1.6$ & $26.9 \pm 0.5$ & $25.6 \pm 1.4$ & $243.9 \pm 1.9$ & $248.4 \pm 2.5$ \\
$\mathrm{~T}_{2}$ & $80.0 \pm 2.0$ & $80.0 \pm 1.6$ & $30.6 \pm 0.6$ & $29.7 \pm 2.2$ & $265.6 \pm 2.1$ & $258.6 \pm 2.1$ \\
$\mathrm{~T}_{3}$ & $78.0 \pm 0.5$ & $79.7 \pm 1.3$ & $33.7 \pm 0.9$ & $29.9 \pm 1.6$ & $260.6 \pm 1.6$ & $261.7 \pm 1.7$ \\
$\mathrm{~T}_{4}$ & $79.7 \pm 1.8$ & $76.7 \pm 0.6$ & $31.6 \pm 1.2$ & $29.1 \pm 1.7$ & $260.3 \pm 2.6$ & $263.9 \mathrm{~b} \pm 2.0$ \\
\hline
\end{tabular}

$\mathrm{T}_{0}$ attained maximum fresh weight of mushroom as accordance with Shah et al. (2004). The difference in compared to any other substrate alone or in combination. Results depicts that $\mathrm{T}_{0}$ yielded (268.8 $\mathrm{g} / \mathrm{bag})$, followed by $\mathrm{T}_{3}(262.1 \mathrm{~g} / \mathrm{bag}), \mathrm{T}_{4}$ and $\mathrm{T}_{2}$ yielded similar $(261.1 \mathrm{~g} / \mathrm{bag})$ while least by $\mathrm{T}_{1}(246.1 \mathrm{~g} / \mathrm{bag})$. Time taken for pinhead formation showed nonsignificant results for variety, treatment and variety treatment interaction. Results indicates that both strains of $P$. eryngii recorded least time to induce pinhead formation at $\mathrm{T}_{4}$ followed by substrate combinations $\mathrm{T}_{3}$, $\mathrm{T}_{2}$ and $\mathrm{T}_{1}$.

\section{DISCUSSION}

Mushroom production depends on several factors e.g. substrate type, availability of nutrients, temperature, humidity, oxygen, carbon dioxide and duration of light (Hassan et al., 2010). Temperature among one of important factors affecting growth and physiological behaviour of mushroom have affected spawn run rate and pinhead formation as optimum results were found at $25^{\circ} \mathrm{C}$ and $17-20^{\circ} \mathrm{C}$ respectively. These outcomes are in morphological growth responses (Table 1) of strains might be affected by different chemical composition of agro-wastes materials (Kazeem et al., 2017). Cotton waste reported best in terms of yield, fresh weight and chemical composition (Jonathan et al., 2012). Differential growth response of strains $\left(\mathrm{P}_{9}\right.$ and $\left.\mathrm{P}_{10}\right)$ of king oyster mushroom (Pleurotus eryngii) on CW and FS could also be attributed to presence of phenolic substances in CW which have a key role in mushroom spawn running and mycelial growth (Bellettini et al., 2016). Results regarding number of days taken to $1^{\text {st }}, 2^{\text {nd }}$ and $3^{\text {rd }}$ flush showed that CW significantly affected yield, time taken to complete flushes and biological efficiency by decreasing number of days. However, it could also be associated with temperature and humidity percentage (Girmay et al., 2016) as 3-4 weeks were taken from pinhead formation to fruit body formation after spawn running at $22^{\circ} \mathrm{C}$ (Shah et al., 2004; Yang et al., 2013). Certain other factors affect the pinhead formation 
(environmental condition of growth room \& physical condition of substrate), yield distribution and final quality of pinhead (Singh et al., 2011). On the other hand, substrate type is a major determinant of mushroom quality, up here in this experiment cotton waste (CW) yielded higher quality of fruiting body (Figure 1) that can be ascribed to high concertation of cellulose and lignocellulose presence in cotton waste (Nasir et al., 2017). These findings are in accordance with the finding of Khan et al., (2004) who concluded that cultivation of Pleurotus ostreatus on different lignocellulosic substrates led to improvement in mean yield $(680.9 \mathrm{~g})$ of mushroom per kg of media. Hernandez et al., (2003) also recommended CW as best available substrate for obtaining higher yields of oyster mushroom (Pleurotus species) among different substrates evaluated. Parallel consequences were concluded by Obodai et al. (2003) who suggested CW as best growing media for cultivation of Pleurotus ostreatus among different eight lignocellulosic by-products evaluated as substrate. This may be due to presence of plenty of nutrients availability in the media along with higher fungal activity (Khan et al., 2017). Biological efficiency (BE) can be described as amount of conversion (\%) of dry substrate weight to fresh mushroom weight (Sharma et al., 2013). Varying results could be due to different strains ( $\mathrm{P}_{9}$ and $\left.\mathrm{P}_{10}\right)$ of Pleurotus ostreatus that are associated with the conclusions of Kirbag and Akyuz (2008), who concluded that higher percentage of BE of Pleurotus eryngii was obtained when grown on various agricultural waste substrates along with supplementation of different chemicals and nutrients.

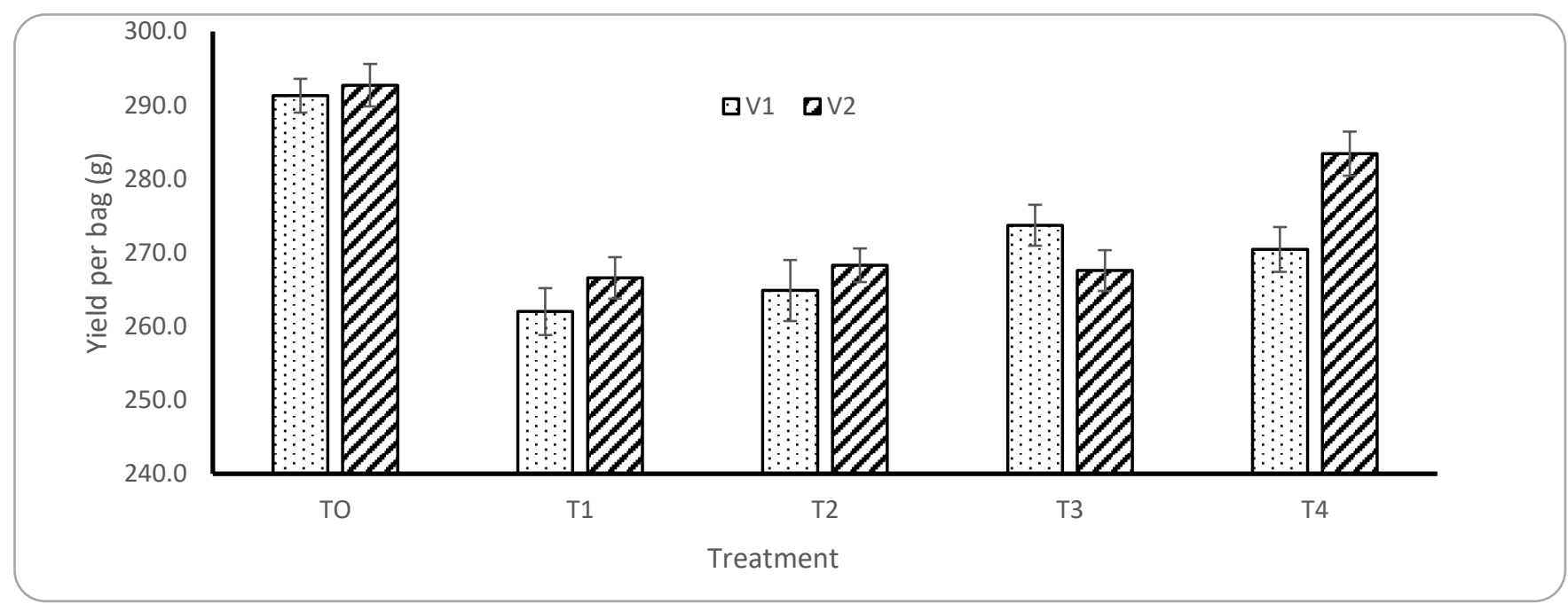

Figure 1. Effect of cotton and fenugreek based substrate and their combination on yield

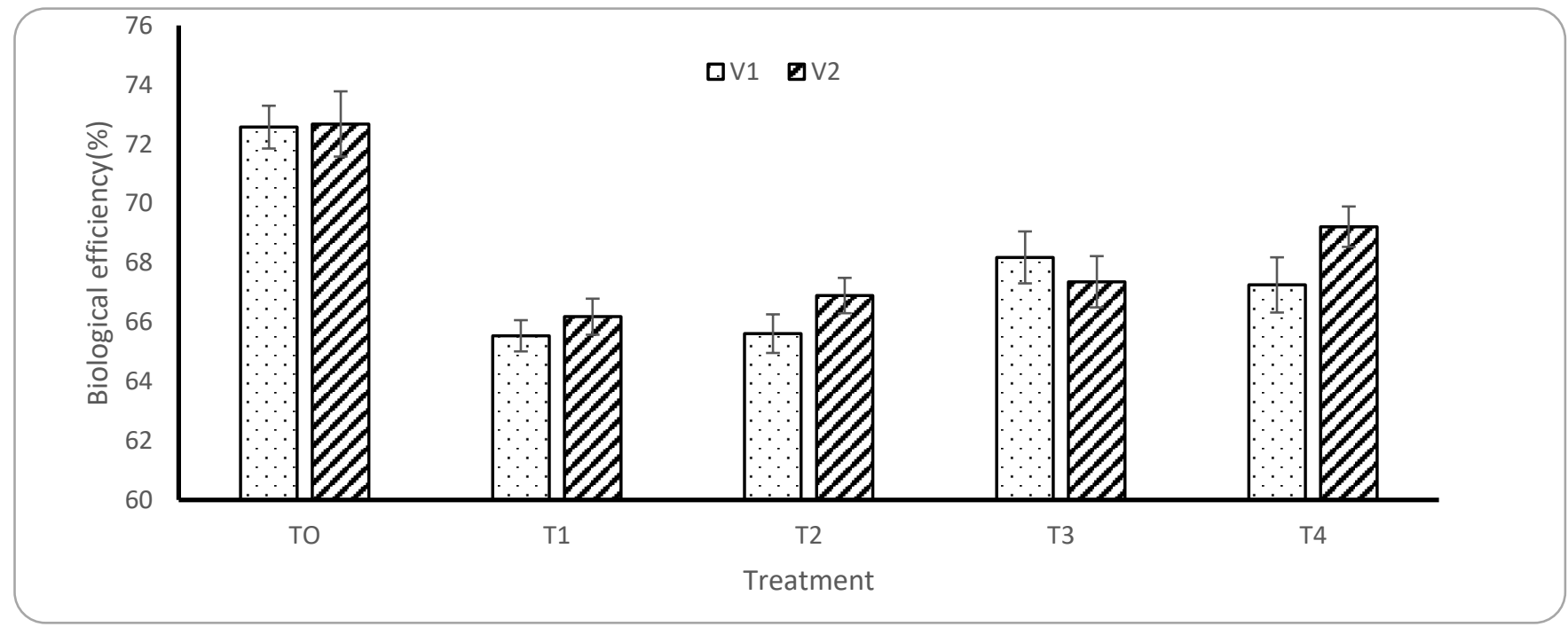

Figure 2. Effect of cotton and fenugreek based substrate and their combination on biological efficiency. 


\section{CONCLUSION}

In this study, we assessed cotton waste and fenugreek straw and their different combination on mushroom production gap, fresh weight, biological yield, biological efficiency, pinhead formation and other physiological parameter of $\mathrm{P}_{9}$ and $\mathrm{P}_{10}$ strains of Pleurotus eryngii. Types of substrate are seriously affect the mushroom production because of increasing and enhancing the enzymatic accessibility of the ingredients for fungus growth and development. It is suggested that production of king oyster mushroom is very capable when cultivated on cotton waste besides fenugreek straw gave an acceptable yield of Pleurotus eryngii.

\section{REFERENCES}

Ahmed, S. A., J. Kadam, V. Mane, S. Patil and M. Baig. 2009. Biological efficiency and nutritional contents of Pleurotus florida (Mont.) Singer cultivated on different agro-wastes. Nature and science, 7: 44-48.

Bellettini, M. B., F. A. Fiorda, H. A. Maieves, G. L. Teixeira, S. Ávila, P. S. Hornung, A. M. Júnior and R. H. Ribani. 2016. Factors affecting mushroom Pleurotus spp. Saudi Journal of Biological Sciences. Gbolagade, J. S., I. O. Fasidi, E. J. Ajayi and A. A. Sobowale. 2006. Effect of physico-chemical factors and semisynthetic media on vegetative growth of Lentinus subnudus (Berk.), an edible mushroom from Nigeria. Food Chemistry, 99: 742-747.

Hassan, F., G. Medany and S. Hussein. 2010. Cultivation of the king oyster mushroom Plerrotus eryngii in Egypt. Australian Journal of Basic and Applied Sciences, 4: 99-105.

Hernández, D., J. E. Sánchez and K. Yamasaki. 2003. A simple procedure for preparing substrate for Pleurotus ostreatus cultivation. Bioresource Technology, 90: 145-150.

Jiskani, M. 1999. A brief outline "The Fungi" (cultivation of mushrooms). Izhar Pub. Tandojam, Pakistan: 94.

Jonathan, S., C. Okon, A. Oyelakin and O. Oluranti. 2012. Nutritional values of oyster mushroom Pleurotus ostreatus (Jacq. Fr.) Kumm. Cultivated on different agricultural wastes. Nature and Science, 10: 186191.

Kazeem, M. O., U. K. M. Shah, A. S. Baharuddin and N. A. Abdul Rahman. 2017. Prospecting Agro-waste Cocktail: Supplementation for Cellulase Production by a Newly Isolated Thermophilic $B$. licheniformis 2D55. Applied Biochemistry and Biotechnology, 182: 1318-1340.

Khan, N. A., S.M. Khan and M.Ashraf. 2004. Bioconversion of rice husk into Pleurotus ostreatus Pak. J. of Agric: 12: 45-52.

Khan, N. A., W. Ahmed, A. Rehman, M. Jahangir and B. Khan. 2017. Efficiency of oyster mushroom Pleurotus columbinus-P 8 using date palm leaves with combination of wheat straw and cotton waste for its yield improvement. Pak. J. Bot: 49(46) 2459-2464.

Kirbag, S. a. A., M. 2008. Evaluation of agricultural wastes for the cultivation of Pleurotus eryngii (DC. ex Fr.) Quel. var. ferulae Lanzi. African Journal of Biotechnology: 7(20).

Manzi, P., S. Marconi, A. Aguzzi and L. Pizzoferrato. 2004. Commercial mushrooms: nutritional quality and effect of cooking. Food Chemistry, 84: 201-206.

Mau, J.-L., P.-R. Chen and J.-H. Yang. 1998. Ultraviolet irradiation increased vitamin D2 content in edible mushrooms. Journal of Agricultural and Food Chemistry, 46: 5269-5272.

Moonmoon, M., M. N. Uddin, S. Ahmed, N. J. Shelly and M. A. Khan. 2010. Cultivation of different strains of king oyster mushroom Pleurotus eryngii on saw dust and rice straw in Bangladesh. Saudi Journal of Biological Sciences, 17: 341-345.

Nasir, M., M. H. Nawaz, U. Latif, M. Yaqub, A. Hayat and A. Rahim. 2017. An overview on enzyme-mimicking nanomaterials for use in electrochemical and optical assays. Microchimica Acta, 184: 323-342.

Obodai, M., J. Cleland-Okine and K. A. Vowotor. 2003. Comparative study on the growth and yield of Pleurotus ostreatus mushroom on different lignocellulosic by-products. Journal of Industrial Microbiology \& Biotechnology, 30: 146-149.

Shah, Z. A., M. Ashraf and M. I. Ch. 2004. Comparative Study on Cultivation and Yield Performance of Oyster Mushroom Pleurotus ostreatus on Different Substrates (Wheat Straw, Leaves, Saw Dust). Pakistan Journal of Nutrition, 3: 158-160.

Sharma, S., Yadav, R. K. P. and Pokhrel, C. P. 2013. Growth and yield of oyster mushroom Pleurotus ostreatus on different substrates. Journal on New Biological Reports: 2(1): 03-08.

Singh, J., N. Mishra, S. Banerjee and Y. C. Sharma. 2011. Comparative studies of physical characteristics of raw and modified sawdust for their use as 
adsorbents for removal of acid dye. Bio. Resources, 6: 2732-2743.

Visscher, H. 1989. Supplementation of the substrate for Pleurotus species at filling. Mushroom Sci, 12: 241-248.

Yang, W., F. Guo and Z. Wan. 2013. Yield and size of oyster mushroom grown on rice/wheat straw basal substrate supplemented with cotton seed hull. Saudi Journal of Biological Sciences, 20: 333338.

Yildiz, S., Ü. C. Yildiz, E. D. Gezer and A. Temiz. 2002. Some lignocellulosic wastes used as raw material in cultivation of the Pleurotus ostreatus culture mushroom. Process Biochemistry, 38: 301-306. 